Review Articles

\title{
The Adenylate Cyclase-Cyclic AMP System in Islets of Langerhans and Its Role in the Control of Insulin Release
}

\author{
G. W. G. Sharp \\ Department of Physiology, Tufts University School of Medicine, Boston, Massachusetts, USA
}

Key words: Adenylate cyclase, phosphodiesterase, protein kinase, phosphoprotein phosphatase, glucose, cyclic AMP, insulin release, islets of Langerhans.

The mechanisms by which glucose and other stimulators control the rate of insulin release from the $\beta$-cells of islets of Langerhans is still far from understood. In general terms, it is assumed that a receptor for a glucose metabolite is the initiator of interactions leading to increased insulin release. These interactions may involve cyclic AMP, $\mathrm{Ca}^{++}$, cytosol components, microfilaments and microtubules, the insulin containing granule membranes and the $\beta$-cell plasma membrane, and lead to fusion of granule membranes with the plasma membrane and the release of insulin from the cell. This short review concentrates on the adenylate cyclase system including the enzyme, its product cyclic AMP, cyclic nucleotide phosphodiesterases which break down cyclic AMP, effector systems for cyclic AMP such as protein kinases and phosphoprotein phosphatases. Inevitably, the interaction with glucose will be an important theme in the discussion because (a) cyclic AMP "potentiates" the insulin-releasing capability of glucose and (b) glucose increases the intracellular concentration of cyclic AMP in islets of Langerhans.

Knowledge that cyclic AMP enhances the $\beta$-cell response to glucose came from the demonstration that glucagon increased insulin secretion and that the response to glucagon was greater during hyperglycaemia that at normal glucose levels [1-4]. By analogy with the effect of glucagon in stimulating adenylate cyclase in liver, it was suggested that cyclic AMP was involved in the mediation of these effects. Since that time, many reports have confirmed the effects of glucagon on insulin release, and the similarities of action between those agents which raise intracellular cyclic AMP levels, such as glucagon, $\beta$-adrenergic agents, phosphodiesterase inhibitors (papaverine, methylxanthines) and cholera toxin, and the effects of exogenous cyclic AMP or dibutyryl cyclic AMP have been noted [5-14]. It is clear from these reports that when the cyclic AMP concentration of the $\beta$-cell is raised, by whatever means, the insulin response to glucose stimulation is enhanced. It is also clear that the effects of cyclic AMP are greatest at high glucose concentrations, whereas at low, non-stimulatory glucose concentrations the effects of cyclic AMP are usually small.

\section{Adenylate Cyclase}

Adenylate cyclase, which catalyzes the formation of cyclic AMP from ATP, is a membrane bound enzyme $[15,16]$ and can be stimulated by hormones interacting at the external surface of the plasma membrane with specific receptor molecules. Thus, one control of the cyclic AMP concentration is the level of circulating hormones. In the case of islet cells, receptors are certainly present for glucagon, ACTH, $\beta$-adrenergic agents and vasoactive intestinal peptide (VIP), while the status and quantitative importance of receptors for secretin and pancreozymin await clarification.

The reports to date are in agreement that glucagon and $\beta$-adrenergic agents stimulate adenylate cyclase although differences in sensitivity and in the extent of the stimulation are apparent, presumably due to differences in preparation of the cells or assay conditions. In an extensive study of a variety of test agents it was found that several hormones stimulated the enzyme [17]. These included ACTH, preparations of secretin and pancreozymin, prostaglandins and acetylcholine. Adenosine at $1-10 \mu \mathrm{mol} / \mathrm{l}$ has 
Table 1. Characteristics of adenylate cyclase in broken cell preparations of endocrine pancreatic cells. $\uparrow=$ increased activity; $\downarrow=$ decreased activity; $-=$ no change detected

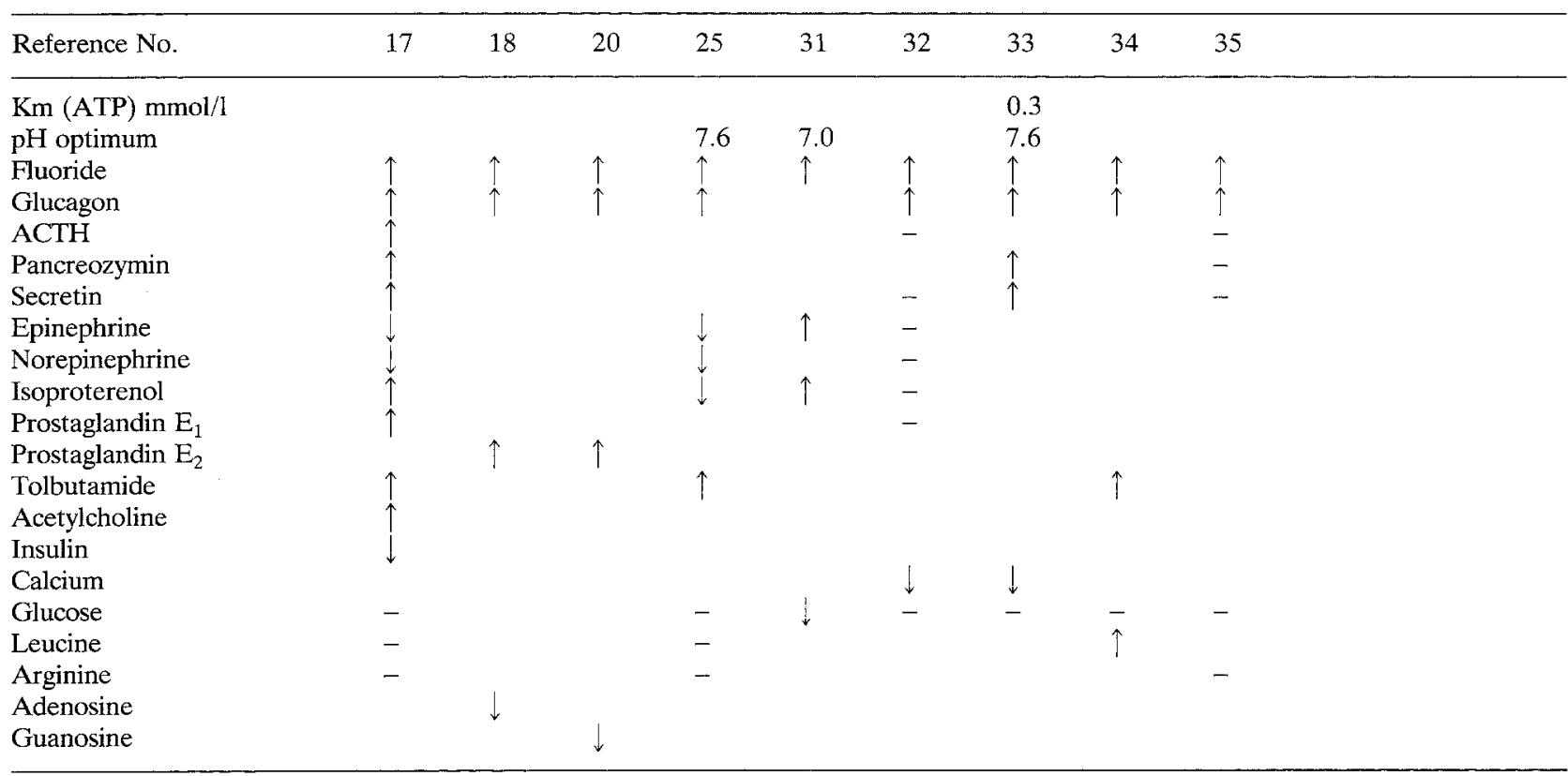

Table 2. Characteristics of phosphodiesterase in islets of Langerhans. $\uparrow=$ increased activity; $\downarrow=$ decreased activity; $-=$ no change detected

\begin{tabular}{|c|c|c|c|c|c|c|c|c|c|}
\hline Reference No. & 17 & 31 & 32 & 37 & 38 & 39 & 40 & 41 & 42 \\
\hline $\mathrm{Km}$ (low) & & & & $2 \mu \mathrm{mol} / 1$ & $3 \mu \mathrm{mol} / 1$ & $10 \mu \mathrm{mol} / 1$ & $10 \mu \mathrm{mol} / 1$ & $6 \mu \mathrm{mol} / 1$ & $1 \mu \mathrm{mol} / 1$ \\
\hline $\mathrm{Km}$ (high) & & & & & $30 \mu \mathrm{mol} / 1$ & $500 \mu \mathrm{mol} / 1$ & & $260 \mu \mathrm{mol} / 1$ & $10-20 \mu \mathrm{mol} / 1$ \\
\hline $\mathrm{pH}$ optimum & & 8.0 & & & 8.7 & & 8.5 & & 8.5 \\
\hline Methylxanthines & $\downarrow$ & $\downarrow$ & $\downarrow$ & $\downarrow$ & $\downarrow$ & $\downarrow$ & $\downarrow$ & & $\downarrow$ \\
\hline Tolbutamide & & & & $\downarrow$ & $\downarrow$ & & $\downarrow$ & & $\downarrow$ \\
\hline Chlorpropamide & & & $\downarrow$ & & & & & & $\downarrow$ \\
\hline Glybenclamide & & & & & $\downarrow$ & $\downarrow$ & & & \\
\hline Imidazole & & & & & $\uparrow$ & $\uparrow$ & & & - \\
\hline Glucose & & & & & - & - & - & & - \\
\hline Leucine & & & & & $\downarrow$ & & & & $\uparrow$ \\
\hline Arginine & & & & & & - & & & $\uparrow$ \\
\hline
\end{tabular}

been reported to inhibit adenylate cyclase and insulin release [18] and to stimulate release strongly at 10 $\mathrm{mmol} / \mathrm{l}[19]$. Guanosine also inhibited insulin release but only inhibited adenylate cyclase when the enzyme was stimulated by the prostaglandin $\mathrm{PGE}_{2}$. In contrast, guanosine strongly inhibited guanylate cyclase [20].

One area which requires further study concerns the ability of $\alpha$-adrenergic agents to inhibit insulin release [3, 21-24]. Inhibitory effects of epinephrine and norepinephrine have been reported on islet adenylate cyclase but only at concentrations as high as $0.1 \mathrm{mmol} / \mathrm{l}[17,25]$. Such high concentrations of catecholamines could be acting non-specifically and may not necessarily reflect a true $\alpha$-adrenergic mechanism. That epinephrine can exert its effect independently of adenylate cyclase in the intact $\beta$-cell was suggested by the fact that even in the presence of exogenous cyclic AMP, epinephrine blocks insulin release [7]. Further, it has been shown that glucagonstimulated insulin release and increased cyclic AMP in islets were inhibited in a parallel dose-dependent fashion by epinephrine while glucose-stimulated insulin release was more sensitive to inhibition by epinephrine than was glucose-induced cyclic AMP accumulation [26]. Thus, at low concentrations epinephrine inhibits glucose-induced insulin release without involvement of the adenylate cyclase-cyclic AMP system. Thus, as is the case in the parotid gland, the $\alpha$-adrenergic inhibitory effect can be mediated by a cyclic AMP-independent $\alpha$-adrenergic mechanism [27]. It seems likely that this mechanism involves an interference with $\mathrm{Ca}^{++}$handling in the $\beta$ cell [28].

Prostaglandins stimulate adenylate cyclase in islets $[17,18,20]$ and would thus be expected to 
enhance insulin release. The data to date are conflicting. Results obtained from administration of prostaglandins to animals and man are difficult to interpret because prostaglandins have diverse actions on many tissues. Thus insulin release will reflect a complex pattern of effects. Unfortunately, the data obtained on isolated islets are also conflicting. Increased insulin release has been reported $[18,20,29]$ as has inhibition of glucose-induced insulin release [30].

One important area of solid agreement until 1977 was the fact that whereas glucose has been shown to increase cyclic AMP concentrations in intact islets, no stimulatory effect of glucose on adenylate cyclase had been demonstrated in the broken cell preparation [17, 25, 31-35]. However, in 1977, there was a report that glucose could stimulate adenylate cyclase in homogenates of mouse pancreatic cells [36]. This finding awaits confirmation and amplification.

The main characteristics of adenylate cyclase in broken cell preparations are shown in Table 1 .

\section{Cyclic Nucleotide Phosphodiesterases}

A second major control over the level of cyclic AMP in islet cells, is the activity of phosphodiesterases which catalyze the breakdown of cyclic AMP to 5' AMP [17, 32, 37-42]. Cells may contain more than one phosphodiesterase which at the present time are identified and defined by their $\mathrm{Km}$ values and by their location. Thus, soluble and particulate, high and low $\mathrm{Km}$ enzymes have been described. Some $70 \%$ of the enzyme is present in the post-microsomal $(105,000 \times \mathrm{g}, 60 \mathrm{~min})$ supernatant [38]. The remaining $30 \%$ is present in the pellet of the low speed centrifugation and very little is present in the mitochondria or microsomes. It is suggested that the low $\mathrm{Km}$ activity is largely in control of cyclic AMP breakdown in the cell because of estimations of intracellular cyclic AMP concentrations close to $\mu$ molar.

In the islet cell tumor of the Syrian hamster, two soluble phosphodiesterases and a particulate phosphodiesterase have been studied [42]. The soluble diesterases were separated on DEAE-cellulose. One was found to represent $15 \%$ and the other $85 \%$ of the total activity. A heat stable protein activator of phosphodiesterase was detected which enhanced the enzyme activity more than two-fold. Thus, the possibility of physiological control of cyclic AMP levels by this activator exists.

No short term or acute effects of glucose have been detected on cyclic nucleotide phosphodiesterase in islets. However, incubation of islets for six days in tissue culture medium containing $16.7 \mathrm{mmol} / \mathrm{l} \mathrm{glu}$ cose did cause an increase in activity [43]. This would correlate with the increased activity of adenylate cyc- lase after long exposure to high glucose concentrations and would permit increased turnover of cyclic AMP in the exposed islets. The effect of glucose was most marked on the low $\mathrm{Km}$ activity. Leucine has been reported to inhibit [38] and to stimulate [42].

A summary of results obtained from studies on phosphodiesterase activity is shown in Table 2.

\section{Protein Kinases}

Protein kinases catalyze the phosphorylation of proteins by the $\gamma$-phosphate of ATP and consist of regulatory subunits and catalytic subunits. Binding of cyclic AMP to the regulatory subunits results in dissociation of the subunit complex. The dissociated catalytic units are then in an active form. In this way, the concentration of cyclic AMP within the cell determines, within limits, the activity of the protein kinase. A further control point lies in the so-called "inhibitory protein" $[44,45]$. This protein is thought to act by combination with a component of the regulatory protein binding site on the catalytic unit. Thus, after cyclic AMP activation and dissociation of the subunits the catalytic subunit might come under the influence of the inhibitory protein. The inhibitory protein is present in different amounts in different tissues [46] but it is not yet known whether it is under physiological regulatory control.

Protein kinase activity in islets was first reported in 1972 [47]. The activity of these enzymes was measured by incubating cell homogenates or subcellular fractions of islets with $\gamma-\mathrm{AT}^{32} \mathrm{P}$, in the presence of $\mathrm{Mg}^{++}$and a suitable buffer solution, and subsequently assaying the amount of ${ }^{32} \mathrm{P}$ transferred to the protein substrate. It was shown that cyclic AMPdependent protein kinase in islets phosphorylated endogenous protein, histones and casein; and that $85 \%$ of the cyclic AMP binding and cyclic AMPdependent protein kinase activities were present in the cytosol fraction. The purified enzyme had a $\mathrm{Km}$ of $10^{-8} \mathrm{~mol} / 1$ for the activation of protein kinase by cyclic AMP. In further studies protein kinase activity was measured in homogenates of islets preincubated with various agents that affect intracellular cyclic AMP levels. It was found that preincubation with IBMX, which raises islet cell cyclic AMP levels, increased protein kinase activity when assayed immediately after the preincubation period [48]. The effect of raised cyclic AMP levels in the intact cells on protein kinase activity was time-dependent, such that 45 minutes after sonication, the enzyme activity had returned to control values. Therefore, maximum effects of cyclic AMP were detected immediately after incubation. A decline in activity occurred thereafter, which was due, presumably, to the reassociation of the catalytic unit of protein kinase with the 
regulatory subunit. Studies with glucagon, theophylline, caffeine, IBMX, glibenclamide and tolbutamide (all agents presumed to increase intracellular cyclic AMP) demonstrated increased protein kinase activity while adrenaline, diazoxide and imidazole (all presumed to decrease cyclic AMP) demonstrated decreased protein kinase activity. Glucose, arginine, leucine and xylitol were without effect. Thus, a close correlation between protein kinase and cyclic AMP content of the islets was obtained, although some workers would have expected glucose also to increase the protein kinase activity by virtue of its ability to raise cyclic AMP levels.

Recently, protein kinases in a transplantable islet cell tumor of the Syrian hamster have been studied and characterized [49]. In these cells, $70-80 \%$ of the homogenate protein kinase activity was recovered in the postmicrosomal supernatant. Cyclic AMPdependent and independent protein kinases were detected. The cyclic AMP-dependent protein kinase made up some $25 \%$ of the total soluble protein kinase activity and could be dissociated into a cyclic AMP binding protein (R) (molecular weight of around 90,000 daltons) and a catalytic subunit (C) of 33,000 daltons. The dissociation was facilitated by $\mathrm{Mg}^{++}$and ATP. The binding protein was further dissociated into smaller subunits by $0.5 \mathrm{~mol} / 1 \mathrm{NaCl}$. The authors proposed that the cyclic AMP-dependent protein kinase in the islet cell tumor was of the form $\mathrm{R}_{2} \mathrm{C}_{2}$ as proposed for other protein kinases. Different substrate specificities were noted between the cyclic AMP-dependent and independent protein kinases. Little work has been performed as yet on specifically localized protein kinases, such as the activity detected in plasma membranes [50], or islet secretory vesicles $[51,52]$. Similarly, little is known yet of the specific substrates for phosphorylation which may be involved in the control of insulin release [53-55].

\section{Phosphoprotein Phosphatases}

It seems obvious that as increased phosphorylation can induce a change in activity of a protein or enzyme, then the reverse process of dephosphorylation is an equally important regulatory influence. Studies on phosphoprotein phosphatase activity in different tissues have demonstrated a broad substrate specificity and a diversity of characteristics and localization [56-58]. These data may reflect a multiplicity of phosphoprotein phosphatases, multiple molecular weight forms [59,60], and a regulatory role of substrate conformation on the enzyme composition.

Little information is available on the characteristics of phosphoprotein phosphatase in islets of Langerhans. Using exogenous labelled substrates activity was found to be increased by $\mathrm{Mg}^{++}$and
$\mathrm{Ca}^{++}$and decreased by inorganic and organic phosphates including phosphorylated intermediates of glucose [61]. While none of these phosphorylated intermediates alone appeared to be capable of exerting physiologically important control over the phosphoprotein phosphatase, it is possible that the enzyme, of which $85 \%$ is in the cytosol, is operating under constant phosphate restraint in the intact cell. Two preliminary reports that cyclic AMP could stimulate phosphoprotein phosphatase activity [62, 63] were not confirmed during later studies [61]. Similarly, cyclic GMP which is reported to stimulate insulin release [64] and proinsulin biosynthesis [65] was without effect. Thus, no evidence exists to date that phosphoprotein phosphatase has a primary regulatory role in the control of insulin release.

\section{Modifications of the Cyclic AMP System in Conditions of Starvation or Glucose Loading}

Starvation reduces the insulin secretory response to glucose [66-71]. Rats starved for $48 \mathrm{~h}$ had decreased insulin responses to glucose which were restored to normal by $24 \mathrm{~h}$ of refeeding [69]. Actinomycin D blocked this restoration so that the results could suggest a glucose-inducible enzyme system which is involved in the changed levels of responsiveness. Very high glucose concentrations restore the maximal secretory capacity of islets of starved animals [41, 72-74] so that an increase in the $\mathrm{Km}$ for glucose stimulation of the release process occurs which could be a consequence of the reduced glucose phosphorylating ability of islets from starved animals [75].

A second line of investigation was initiated by the observation that theophylline administration (in the form of aminophylline) normalized the insulin release response of starved animals [69]. Thus inadequate intracellular cyclic AMP could be a contributory factor in the starvation-induced decrease in insulin release. That the response to glucose in starved animals could be restored by increasing cyclic AMP levels with inhibitors of phosphodiesterase has been confirmed $[41,74]$ but the data on cyclic AMP content of islets of Langerhans in starvation are contradictory. In a 1973 report, islets from rats fasted for 48-72 h had significantly decreased cyclic AMP levels [76]. Since then, four groups have failed to detect significant decreases in cyclic AMP content due to starvation when insulin release was clearly decreased [41, 72-74], though changes in cyclic AMP response to raised glucose concentrations were observed. Thus when fed rats were compared with rats starved for 16 and $48 \mathrm{~h}$, it was clear that the first phase of insulin release was preferentially affected by starvation as was the early cyclic AMP response [72]. However, as a $60 \mathrm{~min}$ incubation of islets from starved rats in the presence of high glucose com- 
pletely restored their responses to normal, the preferential effect upon first phase release and cyclic AMP responses can be viewed as a time-dependent function of the restoration process. In other words, the second phase response appears to be less affected by starvation because restoration has occurred.

Interesting long-term nutritional effects on adenylate cyclase activity in islets of Langerhans have been uncovered. In rats subjected to starvation for 48 $\mathrm{h}$, the basal and glucagon-stimulated activity of adenylate cyclase was reduced markedly while the degree of fluoride stimulation was not significantly affected [77]. By contrast, glucose loading caused a significant increase in basal, glucagon-stimulated and fluoride-stimulated adenylate cyclase activity. That these effects were the result of a glucose effect directly on the islets was shown by incubating islets in the presence of high glucose for up to $24 \mathrm{~h}$. Increased activity of adenylate cyclase, both basal and fluoridestimulated, was detected at two hours. The increase was maximal at $8 \mathrm{~h}$ and was still present at $24 \mathrm{~h}$. Mannose and pyruvate, but not galactose or 2-deoxyglucose, were able to mimic the effects of glucose. Similarly, when islets were cultured for 2 days in 5.6, 8.3 and $16.7 \mathrm{mmol} / 1$ glucose proportional increases in the adenylate cyclase activity were seen [78]. The evidence suggests the existence of regulatory effects of glucose on adenylate cyclase activity which may be involved in the long-term regulation of insulin release. The mechanism by which these effects occur is unknown. The fact that glucose increases the fluoride-stimulatable portion of adenylate cyclase activity could suggest that the synthesis of adenylate cyclase is stimulated. However, the effect of glucose to increase adenylate cyclase after $4-17 \mathrm{~h}$ of incubation was not blocked by inhibitors of protein synthesis [77]. It would appear, therefore, that the effects of glucose are exerted on adenylate cyclase pre-existing in the islets.

\section{Modifications of the Cyclic AMP System in Pregnancy}

Islets of Langerhans from pregnant rats have increased adenylate cyclase activity, raised intracellular cyclic AMP concentrations and increased protein kinase activity when compared with controls $[79,80]$. Thus, a possible explanation for the increased insulin release in the late stages of pregnancy is available. Further information has been obtained from a study in which islets of Langerhans were isolated from female control and pregnant rats and assayed for insulin release, adenylate cyclase, low and high $\mathrm{Km}$ phosphodiesterase, protein kinase in the absence and presence of cyclic AMP and phosphoprotein phophatase [81]. Both phases of glucose-stimulated insulin release were significantly elevated in islets from
20 day pregnant rats while the insulin release seen under basal conditions ( $2.8 \mathrm{mmol} / \mathrm{l} \mathrm{D}$-glucose) was identical in both situations. Associated with the increased insulin release were changes in the enzymes which control cyclic AMP concentration and protein phosphorylation. There was an elevation of the basal adenylate cyclase activity and no detectable change in the physiologically important low $\mathrm{Km}$ phosphodiesterase activity. The increase in the concentration of cyclic AMP $[79,80]$ would be a natural consequence of increased adenylate cyclase activity and no change in the low $\mathrm{Km}$ phosphodiesterase activity [81].

Since cyclic AMP in the presence of glucose is a potentiator of insulin release this would be expected to increase insulin release in pregnancy when blood glucose levels are elevated. Protein kinase and cyclic AMP-dependent protein kinase activity was elevated by $34 \%$ in islets from pregnant animals compared to those from controls. The activity of phosphoprotein phosphatase was not changed. It appears, therefore, that only the positive effectors of the cyclic AMP system, i. e., adenylate cyclase and protein kinases, are elevated in pregnancy while the physiologically active negative effectors are unchanged. This assumes that it is the low $\mathrm{Km}$ phosphodiesterase activity which controls the breakdown of cyclic AMP in islets [43].

Current evidence suggests that the increased activity of adenylate cyclase and cyclic AMP-dependent phosphorylation plays a major role in the increased insulin release observed late in pregnancy. Thus, in perifusion experiments, the rate of insulin relcase by islets from pregnant rats was not elevated under basal $(2.8 \mathrm{mmol} / 1$ glucose $)$ conditions, but was enhanced in the presence of $16.7 \mathrm{mmol} / 1$ glucose [81]. This is in accord with the known activity of cyclic AMP as a potentiator of glucose-induced insulin release. Furthermore, in pregnancy the dose-responses to glucose for insulin release and proinsulin synthesis are shifted to the left $[82,83]$. These, too, are similar to the effects of cyclic AMP on release and biosynthesis [14].

Several possibilities exist for the mechanisms underlying the enzyme changes detected in islets from pregnant rats. Among these, the state of nutrition of the animals is a probable cause of some, if not all, of the changes. For instance, it has been shown that in pregnant rats there is a $20 \%$ increase in food intake near the end of gestation [82]. That this is likely to cause increased adenylate cyclase activity was shown by controlled feeding experiments in which glucose supplementation of the diet was seen to result in $25-50 \%$ increases in adenylate cyclase activity [77]. In addition, when pregnant rats were food-restricted by pair feeding with controls, there was a significant decrease in the insulin release response of the pregnant animals [84]. Thus, the state 
of nutrition of pregnant rats could be one of the major determinants of the increased adenylate cyclase activity and increased insulin release in response to glucose.

Other factors which may be involved include the hypertrophy and increased insulin content of islets from pregnant animals $[82,85]$ and hormonal effects. Thus, human placental lactogen, which increases during pregnancy [86] and then decreases rapidly postpartum, has been shown in hypophysectomized rats to cause increased insulin release in response to glucose and to increase the islet insulin content. Also, estradiol and progesterone, alone and in combination cause changes in insulin release in the range of those seen in pregnancy [87]. The mechanism of these hormonally-induced changes is unknown.

Summarizing the data available, it is clear that increased insulin release response in late pregnancy in rats is apparent in both phases of release [81, 88] and is associated with increased activity of adenylate cyclase, protein kinase and cyclic AMP-dependent protein kinase without alteration of the low $\mathrm{Km}$ phosphodiesterase or phosphoprotein phosphatase activities. It seems likely that these enzyme changes are responsible, at least in part, for the enhanced insulin release response to glucose.

\section{Effect of Glucose on Islet Cyclic AMP Levels}

Interest in the mechanism by which glucose stimulates insulin release was heightened in 1973 by two reports that glucose could increase the amount of cyclic AMP in isolated islets of Langerhans $[89,80]$, despite earlier reports that cyclic AMP levels were not changed by glucose [91-93]. In the work of Charles et al. [89] glucose at $16.7 \mathrm{mmol} / \mathrm{l}$ caused a 2.5 fold increase in the concentration of cyclic AMP in perifused islets which was detectable within 2 minutes of addition of the glucose and still present at 20 minutes after addition. When these results were compared with the effect of theophylline $(10 \mathrm{mmol} / \mathrm{l})$ it was found that the phosphodiesterase inhibitor increased cyclic AMP concentrations 4 fold. From consideration of their results that theophylline caused a greater increase in cyclic AMP content but a lesser increase in insulin release than glucose, the authors concluded that cyclic AMP had only a minor role in directly stimulating insulin release. As glucose and theophylline together increased insulin release and cyclic AMP levels to higher values than glucose alone, they ascribe a prominent role to cyclic AMP in the modulation of glucose-induced insulin release.

The reports by Grill and Cerasi $[90,94]$ were based on the use of ${ }^{3} \mathrm{H}$-adenine and incorporation into ${ }^{3} \mathrm{H}$-cyclic AMP. The method has the disadvantage that the absolute amount of cyclic AMP is not determined and the potential disadvantage that the method assumes no change in the specific activity of the ATP from which it is derived. It would seem, however, that the specific activity of ATP and of cyclic AMP are not influenced by glucose [95]. The method has the advantage of high sensitivity and the ability to measure ${ }^{3} \mathrm{H}$-cyclic AMP efflux from islets. The medium ${ }^{3} \mathrm{H}$-cyclic AMP can reflect, in a cumulative manner, the concentration of cyclic AMP which was present in the cells over prolonged periods of time. It was found that changing the glucose concentration in the medium from 0.6 to $5.0 \mathrm{mg} / \mathrm{ml}(3.3$ to $27.7 \mathrm{mmol} / \mathrm{l}$ ) elicited a significant increase in ${ }^{3} \mathrm{H}$-cyclic AMP accumulation which was magnified by incubation in the presence of a phosphodiesterase inhibitor (IBMX). Later, it was shown that D-glucose stimulated the accumulation of cyclic AMP when measured either by the ${ }^{3} \mathrm{H}$-adenine incorporation technique in the presence or absence of IBMX or by the protein binding assay (in the presence of IBMX) [94]. L-glucose was without effect. Increased accumulation of ${ }^{3} \mathrm{H}$-cyclic AMP in response to glucose was detected 135 seconds after addition of the glucose and showed a phase of rapid increase from 0 to 10 minutes and then a more gradual increase up to 120 minutes. When at 3 minutes after the addition of a high glucose concentration the medium glucose was reduced to $3.3 \mathrm{mmol} / \mathrm{l}$, the ${ }^{3} \mathrm{H}$-cyclic AMP content of the islets returned to control values within 3 minutes. Dose-response studies performed by measurement of the medium content of ${ }^{3} \mathrm{H}$-cyclic AMP 60 minutes after glucose addition showed a good correlation between ${ }^{3} \mathrm{H}$-cyclic AMP and insulin release. The halfmaximal concentration of glucose for both accumulation of cyclic AMP in the medium and of insulin release was $8.3 \mathrm{mmol} / \mathrm{l}$. In a separate study the reduced release of insulin in response to glucose in islets of neonatal rats was associated with an inability of glucose to elevate cyclic AMP levels [96].

Yet another correlation between the effects of glucose on cyclic AMP accumulation and insulin release is the preferential effect of the alpha anomer of glucose on cyclic AMP levels [97] in parallel with its preferential effect on insulin release [98, 99]. These correlations between the concentration of cyclic AMP and insulin release suggest a role for cyclic AMP in the insulin-releasing mechanism of glucose. However, now that the effects of other sugars have been tested, the possibility of a straightforward association between glucose, cyclic AMP and insulin release has become less likely [100]. Extracellular $\mathrm{Ca}^{++}$is essential for the effect of glucose to raise cyclic AMP levels [101, 102].

In another enquiry into the possibility that cyclic AMP mediates the effect of glucose on insulin release it was found that high glucose, glyceraldehyde and dihydroxyacetone caused small increases in cyclic AMP content of islets of the ob/ob mouse, and large 
increases in the presence of IBMX [12]. Cholera toxin, in the presence of $3 \mathrm{mmol} / \mathrm{l}$ glucose, increased cyclic AMP content without stimulating insulin release, while in the presence of IBMX insulin release and cyclic AMP levels were potentiated. In assessing their results, the authors stressed again the discrepancy between the intracellular cyclic AMP levels and insulin release when IBMX or cholera toxin alone was compared with the effects of high glucose. The results suggest that the glucose-induced increase in cyclic AMP concentration has a potentiating effect upon its primary signal to stimulate insulin release. They further suggest that as glyceraldehyde and dihydroxyacetone affect cyclic AMP levels in the same manner as glucose, and as these two compounds feed into the glycolytic pathway, that it is the metabolism, or a metabolite of these compounds which exerts the effect to increase cyclic AMP levels. In the course of this work, the possibility was again suggested that a small, physiologically important pool of cyclic AMP might be the specific stimulus to insulin release.

Several considerations argue against the idea of a separate, compartmentalized adenylate cyclase and cyclic AMP pool. For instance, such an adenylate cyclase would have to be inactive in the absence of glucose or inaccessible to phosphodiesterase inhibitors because cyclic AMP accumulation leading to significant insulin release does not occur with such inhibitors. The cyclase would have to be inaccessible to cholera toxin because of the lack of insulin release following toxin treatment at low glucose concentrations. Furthermore, the compartment served by such a hypothetical insulin-releasing cyclic AMP pool would have to be inaccessible to exogenous cyclic AMP or dibutyryl cyclic AMP. These requirements seem to be so severe as to rule out a specific insulinreleasing pool of cyclic AMP.

\section{The Mechanism of the Effect of Cyclic AMP on Insulin Release}

While little evidence is available to link directly the effect of cyclic AMP by intermediary reactions to the final result of enhanced insulin release, it seems clear that the control of cytosolic $\mathrm{Ca}^{++}$concentrations will be a major factor. Calcium plays an essential role in the stimulus-release coupling and can alone trigger and sustain insulin release when permitted to enter the $\beta$-cells by the use of the divalent cation ionophore A23187 [101, 103, 104]. One could speculate that a cyclic AMP-induced change in the phosphorylation of key proteins could lead to an increased cytosol $\mathrm{Ca}^{++}$concentration and that this increase could augment the increase in cytosolic $\mathrm{Ca}^{++}$caused by glucose. Such a simple mechanism assumes that while cyclic AMP can raise cytosolic $\mathrm{Ca}^{++}$, it cannot raise the level sufficiently in the absence of a glucose stimulus to cause sustained release - hence its dependence on glucose. Such a mechanism for cyclic AMP would presumably involve intracellular organelles and while a detailed discussion of the role of $\mathrm{Ca}^{++}$is inappropriate in this review, mention should be made of evidence for control by cyclic AMP over calcium handling.

${ }^{45} \mathrm{Ca}^{++}$uptake into a microsomal fraction of isolated islets from ob/ob mice has been measured and two types of uptake mechanisms were detected by Scatchard analysis [105]. A high affinity uptake process was stimulated by ATP, but not GTP or CTP, in the presence of $\mathrm{Mg}^{++}$. Significantly the uptake was half-saturated by $10-20 \mu \mathrm{mol} / 1 \mathrm{Ca}^{++}$(i. e., in the probable physiological range of free $\mathrm{Ca}^{++}$concentrations) and was inhibited by $10 \mu \mathrm{mol} / \mathrm{l}$ cyclic AMP. While this is a high concentration of cyclic AMP and the effect was duplicated by cyclic GMP and cyclic CMP, it is possible that a physiological control mechanism is being studied. A similar mechanism has also been detected in which the effect of cyclic AMP was exerted principally on the granule and mitochondrial fraction [106]. The mitochondria have been thought to exert a major controlling role over the concentration of cytosol calcium by virtue of their ability to take up $\mathrm{Ca}^{++}$rapidly and in large quantity [107]. However, until information becomes available on the ability and capacity of intracellular organelles and of the plasma membrane to transport and control $\mathrm{Ca}^{++}$in the cytosol, the precise role of each component will remain unknown.

A unifying theory for the effects of cyclic AMP and glucose on insulin release can be developed along the following lines. Glucose inhibits $\mathrm{Ca}^{++}$ efflux across the plasma membrane of the $\beta$-cell [108-110] thus increasing cytosol $\mathrm{Ca}^{++}$concentration and stimulating insulin release. Cyclic AMP causes inhibition of uptake of cytosol $\mathrm{Ca}^{++}$into intracellular organelles $[105,106]$, which has sufficient effect to raise cytosol $\mathrm{Ca}^{++}$and stimulate insulin release only when the rate of $\mathrm{Ca}^{++}$efflux across the cell membranes is reduced by glucose. Hence, the glucose dependency of the action of cyclic AMP. With respect to the mechanism by which glucose increases intracellular cyclic AMP levels one could speculate that this is a secondary consequence of the action of glucose to raise cytosol $\mathrm{Ca}^{++}$. Calciumdependent regulator proteins are found in a wide variety of tissues and have been demonstrated to activate adenylate cyclase from brain $[111,112]$. If calcium-dependent regulator proteins are present in islets, as in other tissues, their role in the glucoseinduced increases in cyclic AMP levels should be explored. More importantly, the possibility that they mediate the process of $\mathrm{Ca}^{++}$-induced exocytosis should be investigated. 


\section{References}

1. Samols, E., Marri, G., Marks, V.: Promotion of insulin secretion by glucagon. Lancet 1965 II, 415-416

2. Samols, E., Marri, G., Marks, V.: Inter-relationship of glucagon, insulin and glucose. The insulinogenic effect of glucagon. Diabetes 15, 855-866 (1966)

3. Karam, J., Grasso, S., Wegienka, L., Grodsky, G., Forsham, P.: Effect of selected hexoses, of epinephrine, and of glucagon on insulin secretion in man. Diabetes 15, 571-578 (1966)

4. Turner, D. S., McIntyre, N.: Stimulation by glucagon of insulin release from rabbit pancreas in vitro. Lancet $1966 \mathrm{I}$, 351-352

5. Sussman, K. E., Vaughan, G. D.: Insulin release after ACTH, glucagon and adenosine-3', 5'-phosphate (cyclic AMP) in the perfused isolated rat pancreas. Diabetes 16, 449-454 (1967)

6. Malaisse, W. J., Malaisse-Lagae, F., Mayhew, D. A.: A possible role for the adenyl cyclase system in insulin secretion. $\mathrm{J}$. Clin. Invest. 46, 1724-1734 (1967)

7. Malaisse, W. J., Brisson, G., Malaisse-Lagae, F.: The stimulus-secretion coupling of glucose-induced insulin release - I. Interaction of epinephrine and alkaline earth cations. J. Lab. Med. 76, 895-902 (1970)

8. Colwell, A. R., Zuckerman, L.: Regulation of insulin release by pancreatic glucagon. Diabetes 19, 129-137 (1977)

9. Burr, I. M., Balant, L., Stauffacher, W., Renold, A. E.: Perifusion of rat pancreatic tissue in vitro: Substrate modification of theophylline induced byphasic insulin release. J. Clin. Invest. 49, 2097-2105 (1970)

10. Lambert, A. E., Kanazawa, Y., Burr, I. M., Orci, L., Renold, A. E.: On the role of cyclic AMP in insulin release. I. Overall effects in cultured fetal rat pancreas. Ann. N. Y. Acad. Sci. 185, 232-244 (1971)

11. Wollheim, C. B., Blondel, B., Sharp, G. W. G.: Effect of cholera toxin on insulin release in monolayer cultures of the endocrine pancreas. Diabetologia 10, 783-787 (1974)

12. Hellman, B., Idahl, L.-A., Lernmark, A., Täljedal, I.-B.: The pancreatic $\beta$-cell recognition of insulin secretagogues: Does cyclic AMP mediate the effect of glucose? Proc. Natl. Acad. Sci. USA 71, 3405-3409 (1974)

13. Jarousse, C., Rosselin, G.: Interaction of amino acids and cyclic AMP on the release of insulin and glucagon by newborn rat pancreas. Endocrinology 96, 168-177 (1975)

14. Maldonato, A., Renold, A. E., Sharp, G. W. G., Cerasi, E.: Glucose induced proinsulin biosynthesis; role of islet cyclic AMP. Diabetes 26, 538-545 (1977)

15. Howell, S. L., Whitfield, M.: Cytochemical localization of adenyl cyclase activity in rat islets of Langerhans. J. Histochem. Cytochem. 20, 873-879 (1972)

16. Lernmark, A., Nathans, A., Steiner, D. F.: Preparation and characterization of plasma membrane-enriched fractions from rat pancreatic islets. J. Cell Biol. 71, 606-623 (1976)

17. Kuo, W.-N., Hodgins, D. S., Kuo, J. F.: Adenylate cyclase in islets of Langerhans. Isolation of islets and regulation of adenylate cyclase activity by various hormones and agents. $\mathbf{J}$. Biol. Chem. 248, 2705-2711 (1973)

18. Ismail, N. A., El Denshary, E. S. M., Montague, W.: Adenosine and the regulation of insulin secretion by isolated rat islets of Langerhans. Biochem. J. 164, 409-413 (1977)

19. Feldman, J. M., Jackson, T. B.: Specificity of nucleotide-induced insulin secretion. Endocrinology 94, 388-394 (1974)

20. Ismail, N., Montague, W.: Effects of guanosine on insulin secretion and adenylyl and guanylyl cyclase activities of isolated rat islets of Langerhans. Biochim. Biophys. Acta 498, 325-330 (1977)

21. Coore, H. G., Randle, P. J.: Regulation of insulin secretion studied with pieces of rabbit pancreas incubated in vitro. Biochem. J. 93, 67-78 (1964)
22. Porte, D.: A receptor mechanism for the inhibition of insulin release by epinephrine in man. J. Clin. Invest. 46, 86-94 (1966)

23. Porte, D., Williams, R.: Inhibition of insulin release by norepinephrine in man. Science 152, 1248-1250 (1966)

24. Iversen, J.: Adrenergic receptors and the secretion of glucagon and insulin from the isolated perfused canine pancreas. $\mathbf{J}$. Clin. Invest. 52, 2102-2116 (1973)

25. Howell, S. L., Montague, W.: Adenylate cyclase activity in isolated rat islets of Langerhans. Effects of agents which alter rates of insulin secretion. Biochim. Biophys. Acta 320, 44-52 (1973)

26. Rabinovitch, A., Cerasi, E., Sharp, G. W. G.: Cyclic AMP dependent and independent inhibitory effects of epinephrine on insulin release in rat pancreatic islets. Endocrinology 102, $1733-1740$ (1978)

27. Batzri, S., Selinger, Z., Schramm, M., Robinovitch, M. R.: Potassium release mediated by the epinephrine $\alpha$-receptor in rat parotid slices. J. Biol. Chem. 248, 361-368 (1973)

28. Wollheim, C. B., Kikuchi, M., Renold, A.E., Sharp, G. W. G.: Somatostatin- and epinephrine- induced modifications of ${ }^{45}-\mathrm{Ca}^{++}$fluxes and insulin release in rat pancreatic islets maintained in tissue culture. J. Clin. Invest. 60, 1165-1173 (1977)

29. Johnson, D. G., Fujimoto, W. Y., Williams, R. H.: Enhanced release of insulin by prostaglandins in isolated pancreatic islets. Diabetes 22, 658-663 (1973)

30. Burr, I. M., Sharp, R.: Effects of prostaglandin $E_{1}$ and of epinephrine on the dynamis of insulin release in vitro. Endocrinology 94, 835-839 (1974)

31. Atkins, T., Matty, A. J.: Adenyl cyclase and phosphodiesterase activity in the isolated islets of Langerhans of obese mice and their lean litter mates: the effect of glucose, adrenaline and drugs on adenyl cyclase activity. J. Endocrinol. 51, 67-78 (1971)

32. Rosen, O. M., Hirsch, A. H., Goren, E. N.: Factors which influence cyclic AMP formation and degradation in an islet cell tumor of the Syrian hamster. Arch. Biochem. Biophys. 146, 660-663 (1971)

33. Davis, B., Lazarus, N. R.: Insulin release from mouse islets. Effect of glucose and hormones on adenylate cyclase. Biochem. J. 129, 373-379 (1972)

34. Levey, G. S., Schmidt, W. M. I., Mintz, D. J.: Activation of adenyl cyclase in a pancreatic islet cell adenoma by glucagon and tolbutamide. Metabolism 21, 93-98 (1972)

35. Goldfine, I. D., Roth, J., Birnbaumer, L.: Glucagon receptors in $\beta$-cells. Binding of ${ }^{125} \mathrm{I}$-glucagon and activation of adenylate cyclase. J. Biol. Chem. 247, 1211-1218 (1972)

36. Capito, K., Hedeskov, C. J.: Effects of glucose metabolites and calcium ions on adenylate cyclase activity in homogenates of mouse pancreatic islets. Biochem. J. 162, 569-573 (1977)

37. Goldfine, I. D., Perlman, R., Roth, J.: Inhibition of cyclic 3', 5'-AMP phosphodiesterase in islet cells and other tissues by tolbutamide. Nature 234, 295-296 (1971)

38. Sams, D. J., Montague, W.: The role of adenosine 3', 5'cyclic monophosphate in the regulation of insulin release. Properties of islet cell adenosine 3', 5'-cyclic monophosphate phosphodiesterase. Biochem. J. 129, 945-952 (1972)

39. Ashcroft, S.J.H., Randle, P. J., Täljedal, I.-B.: Cyclic nucleotide phosphodiesterase activity in normal mouse pancreatic islets. FEBS Lett. 20, 263-266 (1972)

40. Bowen, V., Lazarus, N. R.: Glucose mediated insulin release: 3', 5'-cyclic AMP phosphodiesterase. Diabetes 22, 738-743 (1973)

41. Capito, K., Hedeskov, C. J.: The effect of starvation on phosphodiesterase activity and the content of adenosine 3, 5'cyclic monophosphate in isolated mouse pancreatic islets. Biochem. J. 142, 653-658 (1974) 
42. Schubart, U.K., Udem, L., Baum, S. G., Rosen, O.M.: Characterization of cyclic 3', 5'-nucleotide phosphodiesterase activity in an islet cell tumor of the Syrian hamster. Mol. Cell. Endocrinol. 1, 227-247 (1974)

43. Berne, C., Andersson, A.: Long-term effects of a high glucose concentration on cyclic nucleotide phosphodiesterase activity in mouse pancreatic islets maintained in tissue culture. Biochem. J. 156, 461-463 (1976)

44. Walsh, D. A., Perkins, J.P., Brostrom, C. O., Ho, E. S., Krebs, E. G.: Catalysis of the phosphorylase kinase activation reaction. J. Biol. Chem. 246, 1968-1976 (1971)

45. Walsh, D. A., Ashby, C. D.: Protein kinases: aspects of their regulation and diversity. Recent Prog. Horm. Res. 29, 329-359 (1973)

46. Ashby, C.S., Walsh, D. A.: Characterization of the interaction of protein inhibitor with adenosine 3', 5'-monophosphate-dependent protein kinases. J. Biol. Chem. 248, 1255-1261 (1973)

47. Montague, W., Howell, S. L.: The mode of action of adenosine 3, 5'-cyclic monophosphate in mammalian islets of Langerhans. Preparation and properties of islet-cell protein phosphokinase. Biochem. J. 129, 551-560 (1972)

48. Montague, W., Howell, S. L.: The mode of action of adenosine $3^{\prime}, 5^{\prime}$-cyclic monophosphate in mammalian islets of Langerhans. Biochem. J. 134, 321-327 (1973)

49. Schubart, U. K., Rosen, O. M.: Characterization of the protein kinase in a transplantable islet cell tumor of the Syrian hamster. Mol. Cell. Endocrinol. 4, 167-182 (1976)

50. Davis, B., Lazarus, N. R.: Regulation of 3', 5'-cyclic AMPdependent protein kinase in the plasma membrane of cod (Gadus callarius) and mouse islets. J. Membr. Biol. 20, 301-318 (1975)

51. Sussman, K. E., Leitner, J. W.: Conversion of ATP into other adenine nucleotides within isolated islet secretory vesicles. Effect of cyclic AMP on phosphorus translocation. Endocrinology 101, 694-701 (1977)

52. Sussman, K. E., Leitner, J. W.: Cyclic AMP stimulated protein kinase activity within the secretory vesicle fraction of rat islets. Biochem. Biophys. Res. Commun.79, 429-437 (1977)

53. Montague, W., Howell, S. L.: The mode of action of adenosine 3', 5'-cyclic phosphate in the regulation of insulin secretion. In: Polypeptide Hormones: Molecular and Cellular Aspects. Ciba Found. Symp. 41, 141-158 (1976)

54. Schubart, U.K., Shapiro, S., Fleischer, N., Rosen, O. M.: Cyclic adenosine 3', 5'-monophosphate-mediated insulin secretion and ribosomal protein phosphorylation in a hamster islet cell tumor. J. Biol. Chem. 252, 92-101 (1977)

55. Lipson. L. G., Vachon, C., Forristall, C. A., Sharp, G. W. G.: Stimulation of specific protein phosphorylation in intact rat islets of Langerhans by both 3-isobutyl-l-methylxanthine and D-glucose. Clin. Res. 26, 530A (1978)

56. Nakai, C., Thomas, J.A.: Properties of a phosphoprotein phosphatase from bovine heart with activity on glycogen synthase, phosphorylase and histone. J. Biol. Chem. 249, 6459-6467 (1974)

57. Khandelwal, R. L., Vandenheede, J. R., Krebs, E. G.: Purification, properties and substrate specificities of phosphoprotein phosphatase(s) from rabbit liver. J. Biol. Chem. 251, $4850-4858$ (1976)

58. Antoniw, J. R., Nimmo, H. G., Yeaman, S. J., Cohen, P.: Comparison of the substrate specificities of protein phosphatases involved in the regulation of glycogen metabolism in rabbit skeletal muscle. Biochem. J. 162, 423-433 (1977)

59. Brandt, H., Killilea, S. D., Lee, E. Y. C.: Activation of phosphorylase phosphatase by a novel procedure: Evidence for a regulatory mechanism involving the release of a catalytic subunit from enzyme - inhibitor complex(es) of higher molecular weight. Biochem. Biophys. Res. Comm. 61, 598-604 (1974)
60. Chou, C.-K., Alfano, J., Rosen, O. M.: Purification of phosphoprotein phosphatase from bovine cardiac muscle that catalyzes dephosphorylation of cyclic AMP-binding protein component of protein kinase. J. Biol. Chem. 252, 2855-2859 (1977)

61. Lipson, L. G., Forristall, C. A., Sharp, G. W. G.: Phosphorylation and dephosphorylation in the control of insulin release: Islet phosphoprotein phosphatase. Diabetes 25, 374 (1976)

62. Dods, R.F., Burdowski, A.: Adenosine 3', 5'-cyclic monophosphate dependent protein kinase and phosphoprotein phosphatase activities in rat islets of Langerhans. Biochem. Biophys. Res. Commun. 51, 421-427 (1973)

63. Sharp, G. W. G., Wollheim, C. B., Mueller, W., Gutzeit, A., Trueheart, P. A., Blondel, B., Orci, L., Renold, A. E.: Studies on the mechanisms of insulin release. Fed. Proc. 34, $1537-1548$ (1975)

64. Voyles, N., Gutman, R. A., Selawry, H., Fink, G., Penhos, J. C., Recant, L.: Interaction of various stimulators and inhibitors on insulin secretion in vitro. Horm. Res. 4, 65-73 (1973)

65. Howell, S. L., Montague, W.: Regulation of guanylate cyclase in guinea pig islets of Langerhans. Biochem. J. 142, 379-384 (1974)

66. Cahill, G. F., Jr., Herrera, M. G., Morgan, A. P., Soeldner, J. S., Steinke, J., Levy, P. L., Reichard, G. A., Jr., Kipnis, D. M.: Hormone-fuel inter-relationship during fasting. J. Clin. Invest. 45, 1751-1769 (1966)

67. Malaisse, W. J., Malaisse-Lagae, F., Wright, P. H.: Effect of fasting upon insulin secretion in the rat. Am. J. Physiol. 213, 843-848 (1967)

68. Buchanan, K. D., Vance, J. E., Williams, R. H.: Effect of starvation on insulin and glucagon release from isolated islets of Langerhans of the rat. Metabolism 18, 155-162 (1969)

69. Grey, N. J., Goldring, S., Kipnis, D. M.: The effect of fasting, diet and actinomycin D on insulin secretion in the rat. J. Clin. Invest. 49, 881-889 (1970)

70. Idahl, L.-A.: Dynamics of pancreatic $\beta$-cell responses to glucose. Diabetologia 9, 403-412 (1973)

71. Turner, D.S., Young, D. A. B.: The effect of fasting and selective refeeding on insulin release in the rat. Acta Endocrinol. (Kbh.) 72, 46-53 (1973)

72. Rabinovitch, A., Grill, V., Renold, A. E., Cerasi, E.: Insulin release and cyclic AMP accumulation in response to glucose in pancreatic islets of fed and starved rats. J. Clin. Invest. 58, 1209-1216 (1976)

73. Wolters, G. H. J., Konijnendijk, W., Bouman, P. R.: Effects of fasting on insulin secretion, islet glucose metabolism, and the cyclic adenosine 3', 5'-monophosphate content of rat pancreatic islets in vitro. Diabetes 26, 530-537 (1977)

74. Gagerman, E., Hellman, B.: Islet contents of cyclic 3', 5'guanosine monophosphate under conditions which affect the cyclic 3', 5'-adenosine monophosphate. Acta Endocrinol. (Kbh.) 86, 344-354 (1977)

75. Malaisse, W. J., Sener, A., Levy, J.: The stimulus-secretion coupling of glucose-induced insulin release. J. Biol. Chem. 251, 1731-1737 (1976)

76. Selawry, H., Gutman, R., Fink, G., Recant, L.: The effect of starvation on tissue adenosine 3', 5'-monophosphate levels. Biochem. Biophys. Res. Commun. 51, 198-204 (1973)

77. Howell, S. L., Green, I. C., Montague, W.: A possible role of adenylate cyclase in the long-term dietary regulation of insulin secretion from rat islets of Langerhans. Biochem. J. 136, 343-349 (1973)

78. Rabinovitch, A., Cuendet, G. S., Sharp, G. W. G., Renold, A. E., Mintz, D. H.: Relation of insulin release to cyclic AMP content in rat pancreatic islets maintained in tissue culture. Diabetes 27, 766-773 (1978)

79. Green, I. C., Howell, S. L., Montague, W., Taylor, K. W.: Regulation of insulin release from isolated islets of 
Langerhans of the rat in pregnancy. The role of adenosine 3', 5'-cyclic monophosphate. Biochem. J. 134, 481-487 (1973)

80. Green, I. C., Perrin, D., Howell, S. L.: Insulin release in isolated islets of Langerhans of pregnant rats. Relationship between glucose metabolism and cyclic AMP. Horm. Metab. Res. 10, 32-35 (1978)

81. Lipson, L. G., Sharp, G. W. G.: Insulin release in pregnancy: Studies on adenylate cyclase, phosphodiesterase, protein kinase and phosphoprotein phosphatase in isolated islets of Langerhans of the rat. Endocrinology 103, 1272-1280 (1978)

82. Green, I. C., Taylor, K. W.: Effects of pregnancy in the rat on the size and insulin secretory response of the islets of Langerhans. J. Endocrinol. 54, 317-325 (1972)

83. Bone, A. J., Taylor, K.W.: Metabolic adaptation to pregnancy shown by increased biosynthesis of insulin in islets of Langerhans isolated from pregnant rats. Nature 262, 501-502 (1976)

84. Green, I. C., Taylor, K. W.: Insulin secretory response of isolated islets of Langerhans in pregnant rats: Effects of dietary restriction. J. Endocrinol. 62, 137-143 (1974)

85. Malaisse, W. J., Malaisse-Lagae, F., Picard, C., FlamentDurand, J.: Effects of pregnancy and chorionic growth hormone upon insulin secretion. Endocrinology 84, 41-44 (1969)

86. Kalkhoff, R. K., Schalch, D. S., Walker, J. L., Beck, P., Kipnis, D. M., Daughaday, W. H.: Diabetogenic factors associated with pregnancy. Trans. Assoc. Am. Physicians 77, 270-280 (1964)

87. Costrini, N. V., Kalkhoff, R. K.: Relative effects of pregnancy, estradiol, and progesterone on plasma insulin and pancreatic islet insulin secretion. J. Clin. Invest. 50, 992-999 (1971)

88. Kalkhoff, R. K., Kim, H.-J.: Effects of pregnancy on insulin and glucagon secretion by perifused rat pancreatic islets. Endocrinology 102, 623-631 (1978)

89. Charles, M. A., Fanska, R., Schmid, F. G., Forsham, P. H., Grodsky, G. M.: Adenosine 3', 5'-monophosphate in pancreatic islets: Glucose-induced insulin release. Science 179, 569-571 (1973)

90. Grill, V., Cerasi, E.: Activation by glucose of adenyl cyclase in pancreatic islets of the rat. FEBS Lett. 33, 311-314 (1973)

91. Montague, W., Cook, J. R.: The role of adenosine 3', 5'cyclic monophosphate in the regulation of insulin release by isolated rat islets of Langerhans. Biochem. J. 122, 115-120 (1971)

92. Miller, E. A., Wright, P. H., Allen, D. O.: Effect of hormones on accumulation of cyclic AMP- ${ }^{14} \mathrm{C}$ in isolated pancreatic islets of rats. Endocrinology 91, 1117-1119 (1972)

93. Cooper, R. H., Ashcroft, S. J. H., Randle, P. J.: Concentration of adenosine 3, 5'-monophosphate in mouse pancreatic islets measured by a protein-binding radioassay. Biochem. J. 134, 599-605 (1973)

94. Grill, V., Cerasi, E.: Stimulation by D-glucose of cyclic adenosine 3', 5'-monophosphate accumulation and insulin release in isolated pancreatic islets of the rat. J. Biol. Chem. 249, 4196-4201 (1974)

95. Grill, V., Borglund, E., Cerasi, E.: Cyclic AMP in rat pancreatic islets. Evidence for uniform labelling of precursor and product with ${ }^{3} \mathrm{H}$ adenine. Biochim. Biophys. Acta 499, 251-258 (1977)

96. Grill, V., Asplund, K., Hellerstrom, C., Cerasi, E.: Decreased cyclic AMP and insulin response to glucose in isolated islets of neonatal rats. Diabetes 24, 746-752 (1975)
97. Grill, V., Cerasi, E.: Glucose-induced cyclic AMP accumulation in rat islets of Langerhans: Preferential effect of the alpha anomer. FEBS Lett. 54, 80-83 (1975)

98. Niki, A., Niki, H., Miwa, I., Okuda, J.: Insulin secretion of anomers of D-glucose. Science 186, 150-151 (1974)

99. Grodsky, G. M., Fanska, R., West, L., Manning, M.: Anomeric specificity of glucose-stimulated insulin release: Evidence for a glucoreceptor? Science 186, 536-538 (1974)

100. Grill, V., Cerasi, E.: Effect of hexoses and mannoheptulose on cyclic AMP accumulation and insulin secretion in rat pancreatic islets. Biochim. Biophys. Acta 437, 36-50 (1976)

101. Charles, M. A., Lawecki, J., Pictet, R., Grodsky, G. M.: Insulin secretion: Inter-relationships of glucose, cyclic adenosine 3', 5'-monophosphate and calcium. J. Biol. Chem. 250, 6134-6140 (1975)

102. Zawalich. W. S., Karl, R. C., Ferendelli, J. A., Matschinsky, F. M.: Factors governing glucose-induced elevation of cyclic adenosine 3', 5'-monophosphate in pancreatic islets. Diabetologia 11, 231-235 (1975)

103. Wollheim, C. B., Blondel, B., Trueheart, P. A., Renold, A. E., Sharp, G. W. G.: Calcium induced insulin release in monolayer culture of the endocrine pancreas. Studies with ionophore A23187. J. Biol. Chem. 250, 1354-1360 (1975)

104. Ashby, J. P., Speake, R. N.: Insulin and glucagon secretion from isolated islets of Langerhans. Biochem. J. 150, 89-96 (1975)

105. Sehlin, J.: Calcium uptake by subcellular fractions of pancreatic islets. Effects of nucleotides and theophylline. Biochem. J. 156, 63-69 (1976)

106. Howell, S. L., Montague, W.: Regulation by nucleotides of 45-calcium uptake in homogenates in rat islets of Langerhans. FEBS Lett. 52, 48-52 (1975)

107. Borle, A. B.: Kinetic analysis of calcium movements in cell culture. V. Intracellular calcium distribution in kidney cells. J. Membr. Biol. 10, 45-66 (1972)

108. Malaisse, W. J., Brisson, G. R., Larry, E. B.: Stimulus-secretion coupling of glucose-induced insulin release. X. Effects of glucose on ${ }^{45} \mathrm{Ca}$ efflux from perifused islets. Am. J. Physiol. 224, 389-394 (1973)

109. Bukowiecki, L., Freinkel, N.: Relationship between efflux of ionic calcium and phosphorus during excitation of pancreatic islets with glucose. Biochim. Biophys. Acta 436, 190-198 (1976)

110. Kikuchi, M., Wollheim, C. B., Cuendet, G., Renold, A. E., Sharp, G. W. G.: Studies on the dual effects of glucose on $\mathrm{Ca}^{++}$efflux from isolated rat islets. Endocrinology 102, 1339-1349 (1978)

111. Brostrom, C. O., Huang, Y.-C., Breckenridge, B. McL. Wolff, D. J.: Identification of a calcium-binding protein as a calcium-dependent regulator of brain adenylate cyclase. Proc. Natl. Acad. Sci. USA 72, 64-68 (1975)

112. Brostrom, C. O., Brostrom, M. A., Wolff, D. J.: Calciumdependent adenylate cyclase from rat cerebral cortex. J. Biol. Chem. 252, 5677-5685 (1977)

Received: November 13, 1978

Geoffrey W. G. Sharp

Department of Physiology

Tufts University School of Medicine

Boston, MA 02111

USA 